\title{
Comparison of Muscle Cross-sectional Area and Lumbar Muscle Strength According to Degenerative Spinal Diseases
}

\author{
Ji-Hoon Cho', Ki-Hyuk Lee², Seung-Taek Lim ${ }^{3,4}$, Buong-O Chun ${ }^{5 *}$ \\ ${ }^{1}$ Department of Sport and Leisure Studies, Shingyeong University, Korea \\ ${ }^{2}$ Center for Sport Science in Jeju, Korea \\ ${ }^{3}$ Institute of Sport Science, Kangwon National University, Korea \\ ${ }^{4}$ Nasaret International Hospital, Korea \\ ${ }^{5}$ Myongji University, Korea
}

\begin{abstract}
Received: September 4, 2019

Accepted: October 30, 2019

Published online: April 30, 2020

Keywords:

Cross-Sectional Area

Degenerative Spinal Diseases

Iliopsoas

Lumbar Extension Muscle Strength

Magnetic Resonance Imaging

Multifidus
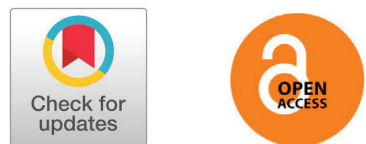

OBJECTIVES The purpose of this study was to investigate the difference in the cross - sectional area (CSA) of multifidus and lliopsoas muscles and the lumbar extension muscle strength according to degenerative spinal diseases (LHI; lumbar herniation of intervertebral disc group, SS; spinal stenosis group, S; spondylolisthesis group).

METHODS The CSA of multifidus and Iliopsoas muscles size were measured by PACS(Picture Achiving and Communication System) using MRI at the L4/5 level and lumbar extension muscle strength $\left(72^{\circ}, 60^{\circ}, 48^{\circ}\right.$, $36^{\circ}, 24^{\circ}, 12^{\circ}, 0^{\circ}$ ) was measured using lumbar extension machine(MedX) in 97 patients of degenerative spinal diseases (male: 57 , female: 40 ). The collected data were analyzed by one-way ANOVA using the SPSS program.

RESULTS The results of this study showed that the CSA of total and right multifidus muscle in the LHI was significantly higher than that of the $S(p<.05 ; p<.05)$ in the male group. The difference between the left and right CSA of multifidus in the LHI group was significantly higher than that of the SS $(p<.05)$ in the male group $(p<.05)$ and total group $(p<.05)$. The CSA of iliopsoas muscle in the $S$ was significantly higher than that of the LHI in the male and total group $(p<.05 ; p<.05)$. In case of lumbar extension muscle strength, the $S$ showed significantly higher muscle strength at 36 and 48 degrees than that of the SS in the male group. In the total group, LHI showed significantly higher muscle strength at 60 degrees of lumbar extension muscle strength than that of the $S$.

CONCLUSION Multifidus muscle appears to be a key factor in prevention and treatment intervention in low back pain patients. In particular, in the case of $\mathrm{S}$ group, exercise therapy for strengthening the multifidus muscle is need for the rehabilitation.
\end{abstract}

(o) The Asian Society of Kinesiology and the Korean Academy of Kinesiology

서론

요통은 전체 인구의 $80 \%$ 이상이 일생 동안 한 번 이상 경험하는 현대사회에 가장 흔하게 발생하는

*Correspondence: Buong-O Chun, Myongji University, 116, Myongji-ro, Cheoin-gu, Yongin-si, Gyeonggi-do, 17058, Republic of Korea; Tel: +82-10-7232-4697; E-mail: tianbingwu@naver.com
통증 중의 하나이다[1]. 요통은 일반적으로 흉추 10 번 이하의 허리부위에 통증이 3 일 이상 지속되는 경 우로[2], 요통과 관련된 척추질환으로는 추간판탈출 증(herniation of intervertebral disc), 척추관협착증 (spinal stenosis), 척추전방전위증(spondylolisthesis), 척추분리증(spondylolysis), 척추불안정증(instability), 
후종인대 골화증(ossification of posterior longitudinal ligament) 등이 있다[3].

요통의 원인으로는 여러가지가 있지만 척추주변 근 육구조의 병적 변화가 영향을 미친다는 연구결과가 보 고되고 있는데[4] 척추질환으로 인한 요통환자들은 관 절운동의 제한과 요추를 지지하는 근육 및 인대의 기능 이 감소하여 신체활동능력이 약 $15 \%$ 정도 감소하는 것 으로 보고되고 있다 $[5,6]$. 더욱이 요통으로 인한 운동 량 감소는 골밀도의 부정적인 효과(negative effects)를 미치게 되고 척추 정렬 및 근골격계 구조의 변형과 근력 감소, 근 위축(atrophy)과 같은 현상이 나타난다 [5, 6]. 따라서 활동 범위가 제한되고 근력은 더욱 감소하는 악 순환이 발생하기에 [7], 요통환자들은 정상인에 비해 배 부의 신전 근력이 더욱 감소하고, 척추 안정화에 중요한 역할을 담당하고 있는 척추주위(paraspinal) 심부근육 의 위축(atrophy)을 유발되게 된다[8].

한편 요통환자의 척추 주변 근 단면적(crosssectional area) 크기와 관련된 선행연구를 살펴보면, 처 음 요통을 경험하게 되면, 뭇갈래근(다열근, Multifidus) 의 위축이 빠르게 발생하며[9], 특히 급성으로 나타난 편측(unilateral) 요통 환자에게서 초음파를 확인한 결 과 편측의 뭇갈래근 크기가 감소하는 비대칭이 나타났 으며 [10, 11], Barker et al. [12] 역시 2주의 기간 동 안 50 명의 요통 환자를 대상으로 뭇갈래근의 위축과 비 대칭을 확인하였다.

이처럼 지금까지의 선행연구들을 살펴보면 요통과 관련된 근육의 위축과 비대칭에 대한 논문은 뭇갈래근 과 관련된 연구가 주를 이루고 있는 실정으로[13], 또 다른 선행연구에서는 만성요통환자의 뭇갈래근이 아 닌 엉덩허리근(장요근, Iliopsoas)과 척추세움근(척추 기립근, Elector Spinae)의 크기의 축소를 보고하였으 나[14-16] 엉덩허리근 및 척추세움근 관련 연구는 뭇 갈래근 관련 연구에 비하여 부족한 실정이다. 더욱이 퇴 행성 척추질환에 따른 뭇갈래근 및 엉덩허리근의 단면 적(cross-sectional area)에 대한 비교 연구는 보고된 바가 없으며 이는 근육의 단면적 크기를 측정하는 선행 연구들 대부분이 컴퓨터 단층촬영 또는 초음파로 진행 되어, 영상의 신뢰성 및 비용적 측면과 촬영에 번거로운 문제점이 발생하기 때문으로 보인다.

이에 본 연구에서는 퇴행성 척추질환에 따른 요통환자 들(추간판탈출증; lumbar herniation of intervertebral disc; LHI, 척추관협착증; spinal stenosis; SS, 척추전 방전위증; spondylolisthesis; S)의 척추주위근육인 뭇 갈래근, 엉덩허리근을 자기공명영상(MRI)을 이용하여 단면적 크기를 분석하여 위축의 정도와 대칭성을 살펴 보고, 요부신전근력을 측정하여 각 질환에 따른 단면적 크기와 요부신전근력의 기준이 될 수 있는 기초자료를 제시하고 각 질환에 따른 차이를 규명하고자 하였다.

\section{연구방법}

\section{연구대상}

본 연구는 척추전문병원에서 실시하는 자기공명영 상검사에서 얻어진 결과를 토대로 전문의로부터 추간 판 탈출증 $(n=37)$, 척추관협착증 $(n=40)$, 척주전방전위 증 $(n=20)$ 진단을 받은 자를 대상으로 하였으며, 대상자 에게는 본인, 보호자 및 신경외과 담당주치의의 실험 참 가 동의서를 받았다.

구체적 선정기준은 제 4 요추-제 5 요추, 제 5 요추-제 1 천추등의 One Level의 요추간탈출증, 척추관협착증, 척 추전방전위증 진단을 받은 만성요통 환자 30-69세 성 인(n=97, 남 57명, 여 40명)으로, 과거 척추수술 및 입 원의 경험을 가지고 있지 않으며, 신경학적인 장애가 없 고, 요부신전근력을 검사하는데 적합한 대상자로 연구 대상자의 신체적 특성은 <Table 1 > 과 같다.

\section{측정방법}

\section{척추주위근육 단면적크기}

본 연구의 종속변인인 뭇갈래근, 엉덩허리근의 근 단 면적 크기, 좌우 대칭성을 분석하기 위하여 자기공명영 상(Magnetic Resonance Imaging; MRI)을 이용하였으 며, 자기공명영상 촬영 후 측정 부위는 근육의 단면적 이 가장 크고 단면적 변화를 가장 잘 측정할 수 있는 제 4 요추체와 제5요추체 상단으로 하였다[17]. 검사방법 은 환자를 바로 누운(supine) 자세를 취하게 한 후 무릎 밑에 쿠션을 받치고, 양쪽에 체중이 균등하게 유지되도 록 하였으며, 위 자세에서 제 4 요추체와 제 5 요추체 상단 (upper end plate)를 촬영 하였으며, 좌측과 우측의 뭇 갈래근, 엉덩허리근의 근 단면적을 측정하였다. 근 단면 적 측정은 이미 촬영된 가로영상(axial image)을 임상 경력이 풍부한 영상의학과 전문의 1 명이 PACS(Picture Achiving and Communication System) Monitor에서 
좌측과 우측의 뭇갈래근, 엉덩허리근 단면의 경계를 따 라 흥미범위(ROI:Regions Of Interest)와 흑백 히스토 그램(grayscale histogram)의 도구를 이용하여 근 단 면적을 측정하였다. 뭇갈래근과 엉덩허리근 둘레 측정 의 정확성을 높이기 위해 촬영사진을 $152.28 \%$ 로 동일 하게 확대하여, 지방, 골격구조, 그리고 다른 연부조직 을 피하여 근육 외곽면을 따라 그렸으며, 각각의 근육 크기와 모양에 따라서 선택된 point 수는 다양하지만 평 균적으로 55 60개 정도였으며, 좌측과 우측의 뭇갈래 근과 엉덩허리근의 근육단면적의 합계는 $\mathrm{mm}^{2}$ 단위로 컴퓨터에 의해 자동 계산되었다[13]. 계산결과를 바탕 으로 단면적크기 및 좌우 대칭성에 대한 분석을 시행하 였으며, 측정의 객관성과 정확성을 위하여 한명의 영상 의학과 전문의가 이미지를 두 번씩 측정 후 평균을 내 는 방법을 선택하였다.

\section{요부신전근력}

요부신전근력은 MedX Lumbar Extension Machine(U.S.A.)를 이용하여 측정하였다<Table $1>$. 모든 검사과정은 University of Florida Center for Exercise Science's Spinal Rehabilitation Certification Program에서 제시하는 Testing protocol 에 의해 진행하였다.

검사 전 대상자들에게 근력측정에 대한 설명과 검사 간 발생할 수 있는 사고에 대하여 유의사항을 인지시킨 후 측정 이전에 약 10 분가량의 준비운동과 기계적응 훈 련을 실시한 후, 실험에 임하게 하였다. 순수한 요부신 전근력만을 측정하기 위하여 측정기에 앉아 하체의 각 근력이 동원되지 못하도록 무릎 지지대, 대퇴 지지대, 골 반지지대, 그리고 발 받침대로 대퇴부와 하지를 고정시 키고, 먼저 최대 굴곡 각도에서 측정을 시작하였다. 요 부신전근력의 최대 정적 근력을 요추의 전 운동범위인 $72^{\circ}$ 의 동작 범위 내에서 $12^{\circ}$ 간격으로 모두 7 각도 $\left(72^{\circ}\right.$, $\left.60^{\circ}, 48^{\circ}, 36^{\circ}, 24^{\circ}, 12^{\circ}, 0^{\circ}\right)$ 에서 측정 하였다. 각 각도 에서의 측정은 통증과 제한된 관절 각도를 참고하여 검 사자의 측정구령과 함께 점증적으로 허리를 신전 시키 면서 3-4초 동안 상부 저항패드를 밀어 최대 힘이 발 휘되면, 1-2초 동안 최대 근력을 유지하도록 하여 기록 을 측정하였다.

검사자는 측정 기기의 전방에 설치되어 있는 근력 발현상태의 화면을 보면서 시각적 피드백을 받아 최대
근력을 발휘할 수 있도록 하였으며 각도 간의 휴식시간 은 환자임을 고려하여 약 30 초 이상으로 충분히 주어 졌으며, 동일한 방법으로 나머지 각도에서 근력을 측정 하였고, 대상자가 느끼는 자각으로 충분한 최대능력을 발휘하지 못 하였을 경우 해당각도에서 재측정 하였다.

\begin{tabular}{lccc}
\multicolumn{3}{l}{ Table 1. Subject characteristics } \\
\hline LHI $(\mathbf{n}=\mathbf{3 7})$ & SS $(\mathbf{n}=\mathbf{4 0})$ & $\mathbf{S}$ ( $\mathbf{n}=\mathbf{2 0})$ \\
\hline Age & $48.3 \pm 5.3$ & $46.4 \pm 4.4$ & $53.6 \pm 4.7$ \\
Height & $168.4 \pm 8.9$ & $169.7 \pm 8.5$ & $167.8 \pm 8.5$ \\
Weight & $65.1 \pm 11.2$ & $66.0 \pm 11.5$ & $65.6 \pm 12.1$ \\
BMI & $22.8 \pm 2.6$ & $22.8 \pm 2.9$ & $23.2 \pm 2.8$ \\
\hline
\end{tabular}

$\mathrm{BMI}$; body mass index, LHI; lumber herniation of intervertebral disc, SS; spinal stenosis, S; spondylolisthesis

\section{자료처리}

본 연구의 자료처리는 window SPSS 23.0 버전 통계 프로그램을 이용하였다. 수집된 자료는 평균과 표준편차 를 산출하였으며 퇴행성 척추질환에 따른 뭇갈래근과 엉 덩허리근의 근단면적, 요부신전근력의 차이를 확인하기 위해 일원 배치분산분석(One-way ANOVA)을 실시하 였으며 사후검증(post-hoc test)은 Bonferroni를 사용 하였다. 모든 통계적 유의수준은 .05 이하로 설정하였다.

\section{결과}

\section{퇴행성 척추질환에 따른 뭇갈래근 단면적의 차이}

뭇갈래근의 단면적을 전체와 성별로 나누어 척추질 환별로 비교 분석한 결과, 퇴행성 척추질환에 따라 남 자는 우측 근 단면적, 좌·우측 단면적 차이, 그리고 뭇갈 래근 총단면적에 있어 유의한 차이가 나타났으나, 여자 는 유의한 차이가 없었으며, 전체는 좌·우측 단면적 차 이에 있어서 유의한 차이가 나타났다.

사후검증결과, 남자는 뭇갈래근 우측 단면적과 총단 면적에서 추간판탈출증 집단이 척추전방전위증 집단보 다 유의하게 높게 나타났으며 $(\mathrm{p}<.05 ; \mathrm{p}<.05)$. 좌·우측 근 단면적의 차이는 추간판탈출증 집단이 척추관협착증 집단보다 유의하게 높게 나타났다 $(\mathrm{p}<.05)$. 전체는 좌·우 측 근 단면적의 차이에 있어서 추간판탈출증 집단이 척 추관협착증 집단보다 유의하게 높게 나타났다 $(\mathrm{p}<.05)$. 자세한 결과는 다음 <Table 2>와 같다. 
Table 2. Difference of CSA of multifidus muscle according to degenerative spinal diseases (Unit: $\mathrm{mm}^{2}$ )

\begin{tabular}{|c|c|c|c|c|c|}
\hline & & LHI $(n=37)$ & SS $(n=40)$ & $S(n=20)$ & p-value \\
\hline \multirow{4}{*}{$\begin{array}{l}\text { Male } \\
\text { (57) }\end{array}$} & MultiRt & $971.2 \pm 232.9$ & $869.0 \pm 190.0$ & $771.1 \pm 140.8$ & $0.020^{2}$ \\
\hline & Multilt & $921.0 \pm 245.6$ & $850.1 \pm 171.1$ & $813.1 \pm 183.3$ & 0.297 \\
\hline & MultiRtLt & $210.3 \pm 182.3$ & $95.8 \pm 82.1$ & $121.2 \pm 113.4$ & $0.018^{1}$ \\
\hline & Totalmulti & $1982.2 \pm 383.6$ & $1719.1 \pm 338.7$ & $1584.2 \pm 283.0$ & $0.046^{2}$ \\
\hline \multirow{4}{*}{$\begin{array}{l}\text { Female } \\
\text { (40) }\end{array}$} & MultiRt & $660.0 \pm 138.5$ & $623.8 \pm 102.4$ & $583.8 \pm 168.6$ & 0.431 \\
\hline & Multilt & $622.8 \pm 121.8$ & $609.2 \pm 90.6$ & $546.7 \pm 70.0$ & 0.309 \\
\hline & MultiRtLt & $89.9 \pm 79.3$ & $63.7 \pm 55.2$ & $105.1 \pm 95.8$ & 0.429 \\
\hline & Totalmulti & $1282.9 \pm 233.8$ & $1233.0 \pm 173.8$ & $1130.5 \pm 214.1$ & 0.308 \\
\hline \multirow{4}{*}{$\begin{array}{l}\text { Total } \\
\text { (97) }\end{array}$} & MultiRt & $811.4 \pm 245.1$ & $777.1 \pm 201.1$ & $714.9 \pm 169.7$ & 0.270 \\
\hline & Multilt & $767.9 \pm 242.6$ & $759.8 \pm 186.8$ & $733.2 \pm 199.9$ & 0.838 \\
\hline & MultiRtLt & $148.5 \pm 150.2$ & $83.8 \pm 74.1$ & $116.4 \pm 106.2$ & $0.052^{1}$ \\
\hline & Totalmulti & $1579.3 \pm 440.8$ & $1536.8 \pm 371.8$ & $1448.1 \pm 335.2$ & 0.487 \\
\hline
\end{tabular}

LHI; lumber herniation of intervertebral disc, SS; spinal stenosis, S; spondylolisthesis, MultiRt; right multifidus muscle, MultiLt; left multifidus muscle, MultiRtLt: different right and left multifidus muscle, Totalmult; Total multifidus muscles

$1=$ significant between $\mathrm{LHI}$ and SS, $2=$ significant between $\mathrm{LHI}$ and $\mathrm{S}$

Table 3. Difference of CSA of iliopsoas muscle according to degenerative spinal diseases (Unit: $\mathrm{mm}^{2}$ )

\begin{tabular}{|c|c|c|c|c|c|}
\hline & & LHI $(n=37)$ & SS $(n=40)$ & $S(n=20)$ & p-value \\
\hline \multirow{4}{*}{$\begin{array}{l}\text { Male } \\
\text { (57) }\end{array}$} & PsoRt & $1603.6 \pm 341.9$ & $1539.9 \pm 307.8$ & $1475.2 \pm 444.0$ & 0.600 \\
\hline & Psolt & $1596.6 \pm 328.1$ & $1542.3 \pm 295.8$ & $1485.5 \pm 380.8$ & 0.638 \\
\hline & PsoRtLt & $91.3 \pm 66.7$ & $133.2 \pm 103.2$ & $184.5 \pm 133.5$ & $0.045^{2}$ \\
\hline & Totalpso & $3200.3 \pm 660.2$ & $3082.2 \pm 579.2$ & $2960.8 \pm 793.7$ & 0.598 \\
\hline \multirow{4}{*}{$\begin{array}{l}\text { Female } \\
(40)\end{array}$} & PsoRt & $928.0 \pm 93.0$ & $932.9 \pm 170.7$ & $774.9 \pm 182.6$ & 0.056 \\
\hline & Psolt & $898.9 \pm 114.0$ & $946.6 \pm 187.8$ & $802.6 \pm 305.0$ & 0.263 \\
\hline & PsoRtLt & $74.4 \pm 69.4$ & $94.3 \pm 52.4$ & $107.5 \pm 76.7$ & 0.476 \\
\hline & Totalpso & $1826.9 \pm 183.0$ & $1879.5 \pm 341.7$ & $1577.5 \pm 483.7$ & 0.127 \\
\hline \multirow{4}{*}{$\begin{array}{l}\text { Total } \\
\text { (97) }\end{array}$} & PsoRt & $1256.7 \pm 420.4$ & $1312.3 \pm 396.7$ & $1265.1 \pm 502.1$ & 0.836 \\
\hline & Psolt & $1238.3 \pm 427.0$ & $1318.9 \pm 389.7$ & $1280.7 \pm 476.3$ & 0.706 \\
\hline & PsoRtLt & $82.7 \pm 67.7$ & $118.6 \pm 88.9$ & $161.4 \pm 122.7$ & $0.008^{2}$ \\
\hline & Totalpso & $2495.0 \pm 840.7$ & $2631.2 \pm 772.1$ & $2545.8 \pm 956.9$ & 0.773 \\
\hline
\end{tabular}

LHI; lumber herniation of intervertebral disc, SS; spinal stenosis, S; spondylolisthesis, PsoRt; right Iliopsoas muscle, PsoLt; left lliopsoas muscle, PsoRtLt: different right and left lliopsoas muscle, Totalpso; Total Iliopsoas muscles

$1=$ significant between LHI and SS, $2=$ significant between LHI and S

\section{퇴행성 척추질환에 따른 엉덩허리근 단면적의 차이}

엉덩허리근의 단면적을 전체와 성별로 나누어 퇴행 성 척추질환별로 비교 분석한 결과, 남자는 좌·우측 단 면적 차이(PsoRtLt)에 있어 유의한 차이가 나타났으나 여자는 유의한 차이가 없었으며, 전체는 좌·우측 단면 적 차이(PsoRtLt)에 있어서 유의한 차이가 나타났다.

사후검증결과, 남자와 전체에서 모두 추간판탈출증
집단보다 척추전방전위증 집단이 근단면적의 차이가 유 의하게 높게 나타났다 $(\mathrm{p}<.05 ; \mathrm{p}<.05)$. 자세한 결과는 다음 <Table 3 >과 같다.

\section{퇴행성 척추질환에 따른 요부신전근력의 차이}

요부신전근력을 전체와 성별로 나누어 척추질환별로 비교 분석한 결과, 퇴행성 척추질환에 따라 남자는 요부 
Table 4. Difference of lumbar extension strength according to degenerative spinal diseases (Unit: Ibs)

\begin{tabular}{|c|c|c|c|c|c|}
\hline & & LHI $(n=37)$ & SS $(n=40)$ & $S(n=20)$ & p-value \\
\hline \multirow{7}{*}{$\begin{array}{l}\text { Male } \\
\text { (57) }\end{array}$} & MEDXO & $118.6 \pm 48.5$ & $97.6 \pm 33.4$ & $124.1 \pm 42.5$ & 0.103 \\
\hline & MEDX12 & $138.8 \pm 51.9$ & $119.1 \pm 30.6$ & $142.3 \pm 28.5$ & 0.121 \\
\hline & MEDX24 & $158.7 \pm 56.7$ & $132.1 \pm 29.6$ & $156.8 \pm 37.5$ & 0.077 \\
\hline & MEDX36 & $177.9 \pm 62.9$ & $131.6 \pm 50.5$ & $171.4 \pm 68.0$ & $0.027^{1}$ \\
\hline & MEDX48 & $190.9 \pm 68.0$ & $127.2 \pm 71.3$ & $184.8 \pm 76.9$ & $0.009^{1}$ \\
\hline & MEDX60 & $182.6 \pm 109.9$ & $87.6 \pm 88.5$ & $89.8 \pm 115.1$ & $0.008^{1,2}$ \\
\hline & MEDX72 & $121.4 \pm 138.7$ & $53.5 \pm 89.8$ & $74.1 \pm 126.5$ & 0.173 \\
\hline \multirow{7}{*}{$\begin{array}{l}\text { Female } \\
\text { (40) }\end{array}$} & MEDXO & $59.9 \pm 30.6$ & $72.3 \pm 17.3$ & $62.7 \pm 15.5$ & 0.346 \\
\hline & MEDX12 & $70.3 \pm 32.2$ & $81.9 \pm 20.4$ & $70.2 \pm 16.1$ & 0.414 \\
\hline & MEDX24 & $80.1 \pm 31.0$ & $90.7 \pm 25.0$ & $75.3 \pm 15.4$ & 0.397 \\
\hline & MEDX36 & $91.6 \pm 33.8$ & $91.5 \pm 35.5$ & $82.3 \pm 18.0$ & 0.817 \\
\hline & MEDX48 & $95.4 \pm 41.5$ & $92.3 \pm 44.9$ & $89.2 \pm 20.8$ & 0.941 \\
\hline & MEDX60 & $107.3 \pm 46.0$ & $92.3 \pm 54.5$ & $76.5 \pm 62.1$ & 0.413 \\
\hline & MEDX72 & $86.0 \pm 75.0$ & $74.2 \pm 69.5$ & $56.2 \pm 61.8$ & 0.660 \\
\hline \multirow{7}{*}{$\begin{array}{l}\text { Total } \\
\text { (97) }\end{array}$} & MEDXO & $88.5 \pm 49.6$ & $88.1 \pm 30.8$ & $105.7 \pm 46.2$ & 0.261 \\
\hline & MEDX12 & $103.6 \pm 54.7$ & $105.2 \pm 32.6$ & $120.7 \pm 42.1$ & 0.342 \\
\hline & MEDX24 & $118.3 \pm 59.9$ & $116.6 \pm 34.3$ & $132.4 \pm 50.0$ & 0.469 \\
\hline & MEDX36 & $133.6 \pm 66.0$ & $116.6 \pm 49.1$ & $144.7 \pm 70.7$ & 0.204 \\
\hline & MEDX48 & $141.9 \pm 73.4$ & $114.1 \pm 64.3$ & $156.1 \pm 78.6$ & 0.068 \\
\hline & MEDX60 & $143.9 \pm 90.6$ & $89.4 \pm 76.8$ & $85.8 \pm 100.6$ & $0.012^{1}$ \\
\hline & MEDX72 & $103.2 \pm 110.5$ & $61.3 \pm 82.5$ & $68.7 \pm 109.6$ & 0.166 \\
\hline
\end{tabular}

LHI; lumber herniation of intervertebral disc, SS; spinal stenosis, S; spondylolisthesis

$1=$ significant between $\mathrm{LHI}$ and $\mathrm{SS}, 2=$ significant between $\mathrm{LHI}$ and $\mathrm{S}$

신전근력 $36,48,60$ 도에 있어서 유의한 차이가 나타났 으며, 여자는 유의한 차이가 나타나지 않았으며, 전체 는 요부신전근력 60도에 있어서 유의한 차이가 나타났 다. 사후검증결과, 남자는 요부신전근력 36도와 48도 에 있어서는 추간판탈출증 집단이 척주전방전위증 집 단보다 유의하게 높게 나타났으며, 60도에 있어서는 추 간판탈출증 집단이 척추관협착증 집단과 척추전방전위 증 집단보다 유의하게 높게 나타났다. 전체는 요부신전 근력 60 도에 있어서 추간판탈출증 집단이 척추전방전 위증 집단보다 근력이 유의하게 높게 나타났다. 자세한 결과는 다음 <Table 4 >와 같다.

\section{논의}

척추는 추간판, 관절낭, 인대와 근육 등에 의해 안정
성을 유지하게 되는데 특히 근육은 척추의 안정성을 유 지하는데 있어 가장 중요하다. 척추 주변에는 여러 근육 들이 존재하는데 여러 선행 연구들은 척추 주변근육들이 요추부 질환의 원인으로 예방 및 치료에 중요한 역할을 담당하는 것으로 보고하고 있다. 척추주변근육의 분류 는 연구자들에 따라 다르지만 뭇갈래근과 엉덩허리근, 척추세움근을 척추주변근육으로 분류한다[18]. 본 연 구에서는 퇴행성 척추질환에 따라 뭇갈래근과 엉덩허리 근의 근단면적을 비교하였으며, 그 결과에 대해 다음과 같이 논의하고자 한다.

본 연구에서 척추 질환에 따른 뭇갈래근의 단면 적을 비교한 결과, 남자의 경우 뭇갈래근 총단면적 (Totalmulti)과 우측단면적(MultiRt)은 척추전방전위 증 $(\mathrm{S})$ 집단이 추간판탈출증 $(\mathrm{LHI})$ 집단에 비해 유의하게 작은 것으로 나타났다. 뭇갈래근은 척추 후방 내측에 위 
치하며 두 개에서 네 개의 분절에 분포하여 척추 안정성 에 중요한 역할을 하는데, 뭇갈래근의 위축과 척추 분 절 기능 이상은 만성 요통과 높은 연관성이 있다[13]. 특히, 뭇갈래근의 위축은 요추체의 국소적인 움직임이 발생 할 때에 요추체에 대한 안정성을 약화시켜 요추를 불안정하게 하여 척추의 전방 전위를 진행시킬 수 있다 [19,20]. 또한, 전위가 진행되면서 발생하는 통증의 증 가는 운동량의 감소를 초래하여 비사용성 위축 또는 반 사적 근수축 억제로 인한 탈신경 위축에 의하여 뭇갈래 근이 지속적으로 위축될 수 있다. 이는 본 연구에서 척추 전방전위증 집단이 추간판탈출증 집단에 비해 뭇갈래근 단면적이 유의하게 작게 나타나게 된 이유로 생각된다. 이와 관련하여 Park et al. [21]과 Wang et al. [22]은 척추전방전위증 환자에서 뭇갈래근의 단면적이 작을수 록 전위 정도가 크게 나타났다고 하였으며, Wallwork et al. [23]과 Hides et al. [24]은 척추전방전위증 환 자의 뭇갈래근 단면적이 정상인에 비하여 유의하게 작 았다고 보고하여 본 연구결과를 지지해주고 있다. 결과 적으로 남성에서 뭇갈래근의 약화는 다른 질환에 비하 여 척추전방전위증에서 크게 나타나는 특징인 것으로 보 이며, 이 근육의 약화를 방치할 경우 전위의 진행이 점 차 악화될 수 있기 때문에 이 질환의 경우 뭇갈래근 강 화에 초점을 맞춘 운동을 수행해야 할 것으로 사료된다.

한편, 남자 및 남녀 전체에서 뭇갈래근 좌·우측의 차 이(MultiRtLt)는 추간판탈출증 집단이 척추관협착증 집 단에 비하여 유의하게 큰 것으로 나타났다. 선행연구는 추간판탈출증과 척추관협착증에서 증상 측면에 따라 편 측 뭇갈래근이 위축되었다고 보고하고 있다[25]. Chen et al. [26]의 연구에 따르면, 추간판탈출증 환자의 뭇갈 래근 부피와 양측 비대칭은 추간판 돌출부분에 따라 근 육의 형태학적 변화와 양측 근육의 비대칭이 명백하게 나타났다고 하여 본 연구결과를 지지해주고 있다. 척추 관협착증은 디스크의 팽윤과 척추후관절의 비후에 의해 척추관이 좁아지는 질환으로 한측으로 추간판이 돌출되 어 통증을 일으키는 추간판탈출증에 비해 편측의 근위축 이 상대적으로 적게 나타난 것으로 생각된다.

본 연구에서 각 질환별로 엉덩허리근의 단면적을 비 교한 결과 집단 간에 엉덩허리근 전체 단면적과 좌측과 우측 각 단면적은 유의한 차이는 나타나지 않아, 엉덩허 리근의 경우 질환별로 큰 차이가 나타나지는 않는 것으 로 나타났다. 그러나 엉덩허리근의 좌·우측 단면적의 차
이는 남자와 전체에서 집단 간에 유의한 차이가 났는데, 척추전방전위증이 추간판탈출증에 비하여 유의하게 큰 좌·우측 비대칭을 보였다. 엉덩허리근은 고관절의 주요 굴곡근으로 척추의 전방에 위치하며, 기립과 앉은 자세 에서 요추와 골반의 안정화에 기여하는 근육이다[27]. 엉덩허리근의 수축은 척추에 압력을 증가시켜 통증을 유 발시킬 수 있으며, 엉덩허리근의 위축은 요통과 디스크 협착과 유의한 관련성이 있는 것으로 보고되어 있다[13, 28]. 선행연구에 의하면 추간판탈출증과 척추관협착증, 척추전방전위증과 같은 요통관련 질환자는 정상인에 비 해 엉덩허리근의 단면적이 유의하게 작은 것으로 보고 되고 있다 $[13,28]$. 요통 질환자의 경우 증상이 나타나 는 쪽에서만 척추 주변 근육의 단면적이 유의하게 감소 하는 것으로 보고되고 있다[14]. 요통이 없는 정상인들 의 경우 척추 주위 근육의 좌측과 우측이 대칭적인 것 으로 알려져 있다[29-31]. 그러나 Dangaria \& Naesh [14]에 의하면 요통 환자에서 증상이 있는 편측의 엉덩 허리근이 반대쪽에 비하여 유의하게 작았다고 보고하였 다. 척추전방전위증의 진행은 척추의 각 분절간 불안정 성을 증가시키고 굴곡-신전 뿐만 아니라 축성-회전성 의 불안정성을 유발한다. 요추의 편측 불안정성은 상대 적으로 다른 편측 근육의 수축과 같은 보상작용을 요구 한다. 엉덩허리근을 구성하는 큰허리근의 경우 척추의 시상면에서 요추의 안정화를 담당하는 근육으로 척추전 방전위증에 의한 축성 불안정성을 보완하기 위하여 상 대적으로 많은 수축을 한 것으로 보이며, 이에 따라 척 추전방전위증에서 엉덩허리근의 좌·우측의 단면적 차이 가 많이 나타난 것으로 생각된다. 한편, 엉덩허리근의 지속적인 편측 수축은 측면의 변연부의 골극 형성을 유 발하여 이차적인 측만까지 동반할 수 있기 때문에 척추 전방전위증의 경우 엉덩허리근의 좌·우측 비대칭이 클 수 있으므로 스트레칭 및 강화운동으로 근육을 대칭적 으로 발달시킬 필요가 있을 것으로 보인다.

허리 근력은 척추의 외적인 안정성을 제공하는데 중 요한 역할을 담당한다[32]. 일반적으로 만성요통환자 들의 경우 약 $80 \%$ 이상이 요추 주위 근육의 근력이 정 상인보다 유의하게 낮은 것으로 알려져 있다[33]. 특히, 요통환자는 요추부의 굴곡근보다 신전근의 약화가 심하 다고 보고하고 있다 $[18,34]$. 본 연구에서 각 질환 별로 요부 신근을 비교한 결과, 남자의 경우 척추관협착증 집 단 $\left(36^{\circ}, 48^{\circ}, 60^{\circ}\right)$ 과 척추전방전위증 집단 $\left(60^{\circ}\right)$ 이 
추간판탈출증 집단에 비해 요부 신근 근력이 유의하게 낮게 나타났다. 즉, 척추관협착증은 추간판탈출증에 비 해 신전의 시작부터 중간까지 근력이 유의하게 낮게 나 타났고, 척추관협착증은 추간판탈출증에 비해 신전이 시작될 때 근력이 유의하게 낮게 나타났다. 일반적으로 기능장애가 심하고 요통이 심할 경우 요부 신근 근력이 낮게 나타나는 것으로 알려져 있다. Park et al. [35]은 요통환자의 요부 신근 근력은 정상인에 비하여 요부신 전위치 $48^{\circ}$ 에서 현저한 감소가 나타났다고 보고하며, 기능장애가 심한 경우 요부 신근이 더욱 약화되는 것으 로 보인다고 하였다. 이는 추간판탈출증이 척추관협착 증과 척추전방전위증에 비해 기능장애가 적을 수 있음 을 시사하는 것이며, 이 같은 이유는 각 질환에서 나타 난 뭇갈래근의 위축과 연관된 결과라고 생각된다. 연구 결과에 따르면 상대적으로 다른 질환에 비해 높은 뭇갈 래근 단면적을 보인 추간판탈출증과 같은 질환에서 높 은 요부 신근 근력이 동일하게 관찰되었다. 선행연구에 의하면 요통환자의 근력약화는 주로 뭇갈래근과 같은 심 부근육계에 의한 것으로 보고되고 있다 $[12,36]$. 이전 연구자들은 만성요통환자에서 척추세움근과 고관절 굴 곡근과 같은 표재근육은 정상인에 비하여 근육의 크기 와 피로율에서 차이가 나타나지 않은 반면, 심부근육인 뭇갈래근의 위축과 피로율이 정상인에 비하여 크게 나 타났다고 보고하였다[12, 37-39]. 또한, $\operatorname{Kim~[40]ㅇㅢ~}$ 연구에서도 뭇갈래근은 요부 신전에 중요한 역할을 하 며, 요부 손상 시 매우 빠르게 위축하는 특성을 보인다 고 하여 요부 신전근력에 있어 뭇갈래근의 중요성을 강 조하였다. 이와 같이 뭇갈래근은 요추부위에 부하가 예 상될 때 사지가 움직이기 이전에 먼저 동원되어 요추부 위 안정화에 기여하고[20], 요추부위의 가장 안쪽에 위 치한 심층 섬유 중 가장 큰 근육으로 체간 신전이 일어 나는 전체 180 도에서 순수하게 요추부의 신전근의 작 용으로 발생하는 72 도까지의 근력을 발휘하는데 가장 핵심적인 근육인 것으로 보이며, 이는 각 질환별로 나 타나는 뭇갈래근 단면적 특성은 실제 요부 신근 근력에 도 영향을 미칠 수 있음을 시사한다.

한편, 여자의 경우 모든 변인에서 남자와 비슷한 경 향을 보였지만 각 질환집단 간에 유의한 차이는 나타나 지 않았다. 여자에서 집단 간 근단면적과 근력에 유의한 차이가 없었던 것은, 여자의 경우 남자와는 다르게 여러
요인에 의하여 개인차가 발생하기 때문인 것으로 보인 다. 특히, 여성호르몬인 에스트로겐(estrogen)은 다양 한 생물학적 과정에 참여하는데, 에스트로겐의 감소는 뼈와 피부의 콜라겐 소모(wasting)를 가속하며, 항산화 활성 및 섬유소 분해에 영향을 미치는 것으로 알려져 있 다 [41, 42, 43]. 에스트로겐은 다양한 근골격계 퇴행성 질환의 병인 및 병태생리학에서 중요한 역할을 하며, 최 근에는 요통과 디스크 변성에도 관련이 있는 것으로 보 고되고 있다[44]. de Schepper et al.[45]은 폐경기 이 후의 여성은 비슷한 연령대의 남성에 비하여 디스크 공 간이 더 좁았다고 하여 상대적인 에스트로겐 수준의 감 소가 생리적 변화와 요추 디스크 변성을 가속화시킨다 고 보고하였다. 선행연구와 같이 여성호르몬에 의한 전 반적인 근골격계 퇴행은 본 연구의 여자 대상자에서 질 환 별로 근력과 근단면적의 차이가 나타나지 않은 것을 어느 정도 설명할 수 있을 것으로 보인다. 향후 호르몬적 변인을 고려한 후속연구가 진행된다면 여자의 질환별 근 단면적과 근력의 차이가 없는 것에 대한 이해를 도울 수 있을 것으로 생각된다. 또한, 본 연구결과에서 여자는 남 자에 비하여 근단면적과 근력이 각각 약 53.3 71.7\%, 약 $34.4 \%$ 낮은 것으로 나타났는데, 이는 여자의 경우 남자와는 다르게 각 질환에서 요추 주변의 전반적인 근 육 강화를 위한 프로그램 구성이 필요함을 시사하며, 이 를 통하여 기본적인 근력과 단면적을 증가시켜 통증 감 소와 신속한 재활을 가져올 수 있을 것으로 생각된다.

\section{결론}

본 연구에서는 퇴행성 척추질환에 따른 근단면적과 요부신전 근력의 차이를 분석한 결과, 뭇갈래근의 단면 적의 차이를 관찰할 수 있었으며 척추전방전위증의 경 우 추간판탈출증에 비하여 유의하게 뭇갈래근의 위축과 요부신전 근력의 감소가 나타났다. 이에 따라 뭇갈래근 은 예방과 치료중재를 위한 핵심적인 요소인 것으로 사 료되며 상태 평가와 재활을 위해서는 뭇갈래근의 강화 를 위한 운동치료가 필요할 것으로 보인다.

\section{Conflicts of Interest}

The authors declare no conflict of interest. 


\section{References}

1. Peter MK, Jennifer LK. The epidemiology of low back pain in primary care. Chiropractic \& Osteopathy. 2005; 13:13.

2. Molumphy M, Unger B, Jenden GM, Lopopolo RB. Incidence of work related low back pain in physical therapist. Physical Therapy. 1985; 65(40):482-86.

3. Kirkaldy WH, Bernard T, Kirkaldy-Willis WH. Managing low back pain. Churchill. 1999.

4. Storheim K, Holm I, Gunderson R, Brox JI, Bø K. The effect of comprehensive group training on cross-sectional area, density, and strength of paraspinal muscles in patients sick-listed for subacute low back pain. J Spinal Disord Tech. 2003; 16(3):271-9.

5. Sinaki M. Effect of physical activity on bone mass. Curr Opin Rheumatol. 1996; 8:376-83.

6. Emily Y, Richard A, Deyo RA. Acute low back pain. Elsevier. 2001; 8:171-74.

7. Kang CY. Therapeutic exercise in low back pain patients. Exercise Professionals Training book. Korean Association of Exercise Professionals. 1999; 155-63.

8. Adams MA \& Rouqhley PJ. What is intervertebral disc degeneration, and what causes it? Spine(PhilaPa1976). 2006; 31(18):2151-61.

9. Kim DH, Park JK, Park YJ, Jung DI, Kim, SU. Characteristic of cross-sectional area of lumbar paraspinal muscle in patients of acute and chronic LBP. The Journal of the Korea Contents Association. 2001; 11(6):270-78.

10. Hides JA, Stokes MJ, Saide M, Jull GA, Cooper DH. Evidence of lumbar multifidus muscle wasting ipsilateralto symptoms in patients with acute/subacute low back pain. Spine. 1994; 19:165-72.

11. Hides JA, Richardson CA, Jull GA. Multifidus muscle recovery is not automatic after resolution of acute, firstepisode low back pain. Spine. 1996; 21(23):2763-69.

12. Barker KL, Shamley DR, Jackson D. Changes in the cross-sectional area of multifidus and psoas in patients with unilateral back pain: the relationship to pain and disability. Spine. 2004; 29(22):E515-9.

13. Danneels LA, Vanderstraeten GG, Cambier DC, Witvrouw
EE, De Cuyper HJ. CT imaging of trunk muscles in chronic low back pain patients and healthy control subjects. Eur Spine J. 2000; 9(4):266-72.

14. Dangaria TR, Naesh O. Changes in cross-sectional area of psoas major muscle in unilateral sciatica caused by disc herniation. Spine (Phila Pa 1976) 1998; 23:928-931.

15. Kamaz M, Kiresi D, Oguz H, Emlik D, Levendoqlu F. CT measurement of trunk muscle areas in patients with chronic low back pain. Diagn Interv Radiol. 2007; 13:144-8.

16. Huang Q, Li D, Zhang J, Yang D, Huo M, Maruyama H. Comparison of the efficacy of different long-term interventions on chronic low back pain using the crosssectional area of the multifidus muscle and the thickness of the transversus abdominis muscle as evaluation indicators. J Phys Ther Sci. 2014; 26(12):1851-4.

17. Tracy MF, Gibson MJ, Szypryt EP, Rutherford A, Corlett EN. The geometry of the muscles of the lumbar spine determined by magnetic resonance imaging. Spine (Phila Pa 1976). 1989; 14(2):186-93.

18. Mayer TG, Vanharanta H, Gatchel RJ, et al. Comparison of CT scan muscle measurements and Isokinetic trunk strength in postoperative patients. Spine (Phila Pa 1976). 1989; 14(1):33-6.

19. Fan S, HuZ, Zhao F, Zhao X, Huang Y, Fang X. Multifidus muscle changes and clinical effects of one-level posterior lumbar interbody fusion: minimally invasive procedure versus conventional open approach. Eur Spine J. 2010; 19(2):316-24.

20. Moseley GL, Hodges PW, Gandevia SC. Deep and superficial fibers of the lumbar multifidus muscle are differentially active during voluntary arm movements. Spine. 2002; 27(2):29-36.

21. Park HS, Kim JI, Kim KW, Cho JH, Song MY. The correlation between cross-sectional area of lumbar paraspinal muscles and sponylolisthesis; a retrospective study. Journal of Korean Medicine Rehabilitation. 2016; 26(1):95-102.

22. Wang G, Karki SB, Xu S, et al. Quantitative MRI and X-ray analysis of disc degeneration and paraspinal muscle changes in degenerative spondylolisthesis. J Back 
Musculoskelet Rehabil. 2014; 28(2):277-85.

23. Wallwork TL, Stanton WR, Freke M, Hides JA. The effect of chronic low back pain on size and contraction of the lumbar multifidus muscle. Man Ther. 2009; 14(5):496500.

24. Hides J, Gilmore C, Stanton W, Bohlscheid E. Multifidus size and symmetry among chronic LBP and healthy asymptomatic subjects. Man Ther. 2008; 13(1):43-49.

25. Kim WH, Lee SH, Lee DY. Changes in the cross-sectional area of multifidus and psoas in unilateral sciatica caused by lumbar disc herniation. J Korean Neurosurg Soc. 2011; 50(3):201-4.

26. Chen ZN, Yao XM, Lv Y, et al. Morphology of the lumbar multifidus muscle in lumbar disc herniation at different durations and at different ages. Exp Ther Med. 2018; 15(5):4119-4126.

27. Enyo Y, Yoshimura N, Yamada H, Hashizume H, Yoshida M. Radiographic natural course of lumbar degenerative spondylolisthesis and its risk factors related to the progression and onset in a 15-year community-based cohort study: the Miyama study. J Orthop Sci. 2015; 20(6):978-84.

28. Parkkola R, Rytökoski U, Kormano M. Magnetic resonance imaging of the discs and trunk muscles in patients with chronic low back pain and healthy control subjects. Spine (Phila Pa 1976) 1993; 18:830-6.

29. Hides JA, Richardson CA, Jull GA. Magnetic resonance imaging and ultrasonography of the lumbar multifidus muscle. Comparison of two different modalities. Spine (Phila Pa 1976). 1995; 20(1):54-8.

30. Pressler JF, Heiss DG, Buford JA, Chidley JV. Betweenday repeatability and symmetry of mulfifidus crosssectional area measured using ultrasound imaging. J Orthop Sports Phys Ther 2006; 36(1):10-8.

31. Watson T, McPherson S, Starr K. The association of nutritional status and gender with cross-sectional area of the multifidus muscle in establishing normative data. J Man Manip Ther. 2008; 16(4):F93-8.

32. Morris JM, Lucas DB, Bresler B. Role of the trunk instability of the spine. J Bone Joint Surg. 1961; 43(3):327-51.
33. Beimborn DS, Morrissey MC. A review of the literature related to trunk muscle performance. Spine (Phila $\mathrm{Pa}$ 1976). 1988; 13(6):655-60.

34. Lee SH, Kim SJ. Isokinetic evaluation of the trunk flexors and extersors in chronic low back pain. Ann Rehabil Med. 1994; 18(2):248-55.

35. Park WH, Lee CS, Kang KC, Seo YG. Characteristics of back muscle strength in patients with scheduled for lumbar fusion surgery due to symptomatic lumbar degenerative diseases. Asian Spine J. 2014; 8(5):659-66.

36. Hodges PW, Richardson CA. Delayed postural contraction of transversus abdominis in low back pain associated with movement of the lower limb. J Spinal Disord. 1998; 11(1):46-56.

37. Biedermann H, Shanks G, Forrest W, Inglis J. Power spectrum analyses of electromyographic activity. Discrimiantors in the differential assessment of patients with chronic low back pain. Spine (Phila Pa 1976). 1991; 16(10):1179-84.

38. Danneels LA, Coorevits PL, Cools AM, et al. Differences in multifidus and iliocostalis lumborum activity between healthy subjects and patients with subacute and chronic low back pain. Eur Spine J. 2002; 11(1):13-9.

39. Hides J, Richardson C, Jull G. Multifidus recovery is not automatic following resolution of acute first episode of low back pain. Spine (Phila Pa 1976). 1996; 21(23):27639.

40. Kim HS. The effects of trunk stabilization exercise on the postural control in chronic low back pain. 2008; Unpublished doctoral dissertation, Daegu University, Kyungbuk, Korea.

41. Brincat M, Moniz CF, Studd JW, Darby AJ, Magos A, Cooper D. Sex hormones and skin collagen content in postmenopausal women. Br Med J (Clin Res Ed). 1983; 287(6402):1337-8.

42. Bolognia JL, Braverman IM, Rousseau ME, Sarrel PM. Skin changes in menopause. Maturitas.1989; 11(4):295-304.

43. Tostes RC, Nigro D, Fortes ZB, Carvalho MH. Effects of estrogen on the vascular system. Braz J Med Biol Res. 2003; 36(9):1143-58.

44. Srikanth VK, Fryer JL, Zhai G, Winzenberg TM, 
Hosmer D, Jones G. A meta-analysis of sex differences prevalence, incidence and severity of osteoarthritis. Osteoarthritis Cartilage. 2005; 13(9):769-81.

45. de Schepper EI, Damen J, van Meurs JB, et al. The association between lumbar disc degeneration and low back pain: the influence of age, gender, and individual radiographic features. Spine (Phila Pa 1976). 2010; 35(5):531-6. 